\title{
The effect of isotretinoin on triglycerides and liver aminotransferases
}

Influência da isotretinoína nas transaminases hepáticas e triglicerídeos

\author{
Andreia Salezze Vieira ${ }^{1}$ \\ Ana Carolina Melchiors ${ }^{3}$
}

\author{
Vanessa Beijamini ${ }^{2}$
}

\begin{abstract}
BACKGRound: Isotretinoin has been used to treat the most severe cases of acne; however, it may provoke adverse events in mucocutaneous and hepatic tissues, lead to alterations in lipid levels and cause teratogenicity.

OвJестіve: The objective of this study was to evaluate the profile of changes in alanine aminotransferase (ALT), aspartate aminotransferase (AST) and triglyceride levels in patients who had been treated with oral isotretinoin dispensed by the São Mateus/ES pharmacy for special drugs.

МетноDs: A retrospective, observational, longitudinal study was conducted by carrying out a secondary analysis of each patient's data.

Results: Of the 130 patients who received isotretinoin between January and December 2009, only 70 were actually treated for 3 months or more and handed in the results of their laboratory tests. Of these 70 patients, $39(55.7 \%)$ were female. The mean age of the women (23.9 years) was higher than the mean age of the men (20.1 years). There was a statistically significant increase in the levels of triglycerides $(87.01 \pm 48.25$ versus $105.32 \pm 48.76 \mathrm{mg} / \mathrm{dL})$, AST $(20.44 \pm 6.26$ versus $24.38 \pm$ $11.92 \mathrm{U} / \mathrm{L})$ and ALT $(18.24 \pm 8.31$ versus $23.34 \pm 20.03 \mathrm{U} / \mathrm{L})$ performed prior to and 3 months or more after oral isotretinoin treatment. After treatment with oral isotretinoin, triglyceride levels had increased beyond the normal range in $11 \%$ of the patients, while $8.6 \%$ had elevated AST levels and 7.3\% had increased ALT levels.

Conclusion: The results in this population show that the use of oral isotretinoin for the treatment of acne may result in altered triglyceride, AST and ALT levels. These findings are in accordance with data published previously in the scientific literature, confirming the need to monitor these patients.
\end{abstract}

Keywords: Acne vulgaris; Aminotransferases; Dermatologic agents; Isotretinoin; Triglycerides

Resumo: FundAMENTOS: A isotretinoína tem sido usada no tratamento dos casos mais graves de acne, embora possa induzir reações adversas nos tecidos mucocutâneos e hepáticos, alterações nos níveis lipídicos e teratogenicidade.

Oвjetivos: Este estudo avaliou o perfil de alterações nas concentrações de Alanina Aminotransferrase, Aspartato Aminotransferrase e triglicerídeos em pacientes que fizeram uso de isotretinoína oral fornecida pelo serviço Farmácia de Medicamentos Excepcionais de São Mateus/ES.

MÉToDos: Foi realizado estudo observacional longitudinal exploratório retrospectivo, utilizando coleta de dados secundários de cada paciente. Resultados: Dos 130 pacientes que receberam isotretinoína no período de janeiro a dezembro de 2009, somente 70 realizaram o tratamento por 3 meses ou mais e apresentaram os resultados dos exames. Desses 70 pacientes, 39 (55,7\%) eram do sexo feminino. A média de idade das mulheres (23,9 anos) foi maior do que a média de idade dos homens (20,1 anos). Houve aumento estatisticamente significante nas dosagens de triglicerídeos $(87,01 \pm 48,25$ versus 105,32 \pm 48,76), Aspartato Aminotransferrase $(20,44 \pm 6,26$ versus $24,38 \pm 11,92)$ e Alanina Aminotransferrase $(18,24 \pm 8,31$ versus $23,34 \pm 20,03)$, realizadas antes e após 3 meses ou mais de tratamento com isotretinoína oral. Após o tratamento com isotretinoína oral, $11 \%$ dos pacientes apresentaram elevação de triglicerídeos acima dos valores normais, 8,6\% apresentaram elevação da Aspartato Aminotransferrase e 7,3\% tiveram elevação da Alanina Aminotransferrase.

ConclusÃo: Os resultados mostraram que o uso de isotretinoína oral para o tratamento da acne, na população estudada, pode levar a alterações nas dosagens de triglicerídeos, Alanina Aminotransferrase e Aspartato Aminotransferrase, como mostrado pela literatura científica, confirmando a necessidade de monitoramento.

Palavras-chave: Acne vulgar; Agentes dermatológicos; Isotretinoína; Transaminases; Triglicerídeos

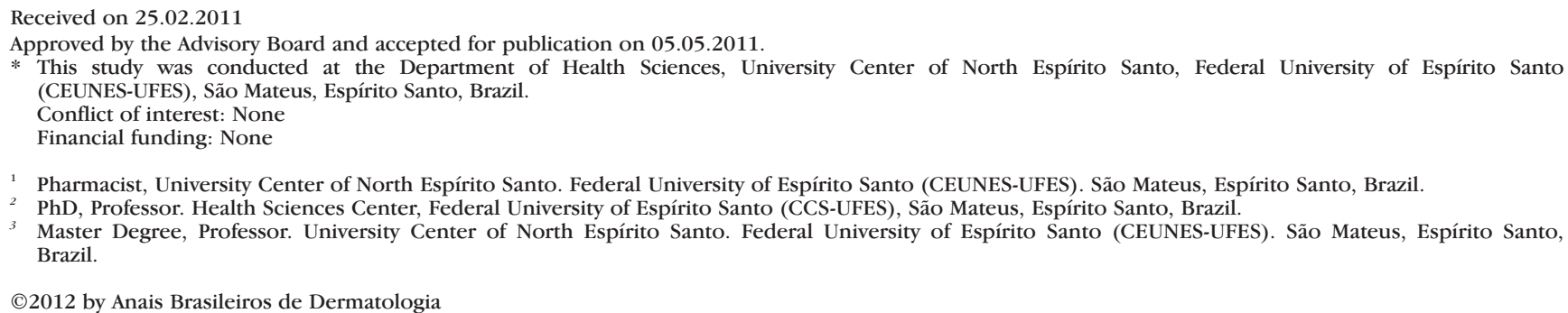




\section{INTRODUCTION}

Acne is an extremely common pathology worldwide, affecting around $79-95 \%$ of adolescents in the western world. ${ }^{1}$ In Brazil, acne is reported to be the most common reason for dermatological consultations, being responsible for $14 \%$ of these consultations in the country. ${ }^{2}$ Acne is a chronic inflammatory condition that develops in the pilosebaceous units. The comedone, which consists of a blocking of the follicular duct with sebum and keratin, forms the primary lesion. ${ }^{3}$

This pathology is classified into two types: inflammatory and non-inflammatory acne, although both types may coexist. The disease may be clinically separated, therefore, into four classification levels: grade 1, the mildest form of non-inflammatory acne, with the presence of comedones; grade II, inflammatory or papulopustular acne in which papules and pustules are associated with comedones; grade III, nodulocystic acne in which nodules are also present; and grade IV, conglobate acne. ${ }^{4}$

The treatment of acne depends on its severity and in cases of non-inflammatory acne or mild inflammatory acne treatment consists entirely of topical products such as tretinoin, isotretinoin, adapalene, benzoyl peroxide and azelaic acid, either alone or in combination. In more severe cases of acne, systemic treatment with antibiotics or isotretinoin may be used. On the other hand, when acne is caused by hyperandrogenism of adrenal or ovarian origin such as in the case of polycystic ovary syndrome, treatment should be in accordance with the origin of the excess androgen production. $^{5}$

The use of isotretinoin or 13-cis-retinoic acid is recommended for the treatment of severe inflammatory acne of the nodulocystic or conglobate types and for cases of acne that have proven resistant to previous treatments with antibiotics or topical medication. ${ }^{6,7}$ In these cases, the doses of isotretinoin range from 0.5 $\mathrm{mg} / \mathrm{kg} /$ day to $2 \mathrm{mg} / \mathrm{kg} /$ day over a period ranging from 16 to 24 weeks. This drug should be used until a maximum cumulative dose of $120-150 \mathrm{mg} / \mathrm{kg}$ of the medication is reached. In addition, many studies have shown that the cumulative dose is more important than the daily dose for remission of the disease. ${ }^{3,7,8}$

Isotretinoin probably acts on the sebaceous gland by binding to specific retinoid receptors, modifying gene transcription. The drug reduces the activity and size of the gland, decreasing the quantity of sebum it produces following four weeks of treatment. Furthermore, retinoids such as isotretinoin act by normalizing keratinization in the sebaceous follicle and the number of Propionibacterium acnes.

This drug has a considerable number of adverse effects. Of these, teratogenicity is the most signifi- cant, while mucocutaneous effects including cracked lips, dryness of the skin and nose, redness of the skin, eye irritation and deterioration of the acne are the most common. ${ }^{8}$ The ocular-related side effects include poor tolerance to contact lenses, increased $S$. aureus infection and photophobia. Other less common side effects consist of fatigue, weakness, hair loss and headache. ${ }^{10-12}$

Isotretinoin use may also lead to liver alterations such as increased serum levels of liver enzymes (liver aminotransferases) and to lipid changes, including increased triglyceride, total cholesterol and low-density lipoprotein (LDL) cholesterol levels and reduced levels of high density lipoprotein (HDL) cholesterol. ${ }^{10-12}$

In humans, the increase in plasma triglyceride levels due to the use of retinoids is accompanied by an increase in apolipoproteins C-III levels, which may contribute, at least in part, to the hypertriglyceridemia induced by retinoids. Nevertheless, other studies are required to determine whether retinoids affect plasma triglyceride levels by regulating the genes that control triglyceride metabolism. ${ }^{13}$

Due to the clinical significance of the possible adverse reactions caused by isotretinoin, the Clinical and Therapeutic Guidelines Protocol issued by the Brazilian Ministry of Health recommends carrying out liver function tests (ALT and AST), total cholesterol, triglycerides, glucose, full blood count, platelets and prothrombin time. In addition, a pregnancy test is required prior to initiating treatment with the drug. The presentation of the abovementioned test results is mandatory for the patient to receive the drug at the pharmacies for special drugs. To continue treatment with isotretinoin, repeat ALT, AST and triglyceride measurements are requested after 30 days and every three months thereafter. ${ }^{6}$

In Brazil, studies to evaluate the prevalence of alterations in aminotransferases and triglycerides in patients using oral isotretinoin are rare..$^{14,15}$ This type of evaluation is important in order to confirm the need for laboratory monitoring of the adverse reactions induced by the oral use of isotretinoin, as well as to supply data to facilitate the planning of preventive actions managed by multidisciplinary teams.

Therefore, the objective of the present study was to evaluate the profile of alterations in ALT, ASL and triglyceride levels in patients using oral isotretinoin for the treatment of severe cases of acne. The drug was supplied in 2009 by the pharmacy for special drugs in the municipality of São Mateus.

\section{MATERIAL AND METHODS}

A retrospective, observational and longitudinal study was conducted in the municipality of São 
Mateus in the Brazilian state of Espírito Santo, based on a secondary data analysis. All the patients who had received oral isotretinoin at a pharmacy for special drugs in the town during 2009 were included in this exploratory study. Exclusion criteria consisted of patients who had discontinued the use of isotretinoin and/or had not provided the pharmacy with the test results needed to enable treatment to be monitored. Each patient's clinical record form was self-completed with information on age, weight, skin color, address and city of residence. In addition, a copy of the laboratory tests performed and a copy of the prescription were attached to the patient's records together with other documents. The study data were collected by analyzing each patient's clinical records.

The study was conducted in accordance with Resolution 196/96 of the Brazilian National Health Council that regulates research studies involving human beings. The project was approved by the Internal Review Board of the University Center of North Espirito Santo, Federal University of Espirito Santo. Since the study consisted of a secondary data collection, no informed consent form was required.

Analysis of normal and abnormal AST, ALT and triglyceride levels was based on the National Cancer Institute (NCI) Common Terminology Criteria for Adverse Events (CTCAE) version 3.0. ${ }^{16}$ CTCAE consists of a five-level system for grading severity (grade 1 corresponding to no complications - grade 5 corresponding to death) that is used to classify adverse reactions (NCI, 2006). AST and ALT measurements were defined as: normal: $\leq 40 \mathrm{U} / \mathrm{L} ;$ grade 1: $41-100 \mathrm{U} / \mathrm{L} ;$ grade 2: 101-200 U/L. Triglyceride levels were classified as: normal: $\leq 150 \mathrm{mg} / \mathrm{dL} ;$ grade $1: 151-375 \mathrm{mg} / \mathrm{dL} ;$ grade 2: $376-750 \mathrm{mg} / \mathrm{dL}$.

Statistical analysis was performed using the SPSS ${ }^{\circledR}$ software program, version 17.0 for Windows. The choice of the statistical tests was based on sample size and on the normal distribution of the data according to the Kolmogorov-Smirnov test to verify whether parametric or non-parametric tests should be applied. In the case of variables with a normal distribution (parametric), Student's t-test was used to compare means between two groups and ANOVA for three or more groups. To compare proportions, Fisher's exact test was used. To establish correlations between variables, Spearman's correlation coefficient was calculated. Results with $\mathrm{p}<0.05$ were considered statistically significant.

\section{RESULTS}

Between January and December 2009, 130 patients initiated treatment with isotretinoin dispensed by the town's pharmacy for special drugs. Of these, 60 patients were excluded from the study because they had not completed a minimum treatment period of three months (26 patients) or had not presented the tests required to enable treatment to be monitored (34 patients). Therefore, the study sample consisted of 70 patients from a total population of 130 individuals, with a 95\% significance level and $8 \%$ error.

The study population consisted of 39 women (55.7\%) and 31 men (44.3\%). Age ranged from 13 to 42 years, with a mean of 22.2 years. The mean age of the women was $23.9 \pm 6.30$ years compared to $20.1 \pm$ 5.66 years for the men. This difference was statistically significant $(\mathrm{F}=6.86 ; \mathrm{p}<0.05)$. Regarding skin color, $61.4 \%$ of the participants declared themselves to be white, $31.4 \%$ brown-skinned and $5.7 \%$ black, while one individual (1.4\%) failed to answer this question. Sixty-nine of the patients provided information on their weight, which ranged from 43 to $120 \mathrm{~kg}$, with a mean of $63.3 \mathrm{~kg}$.

The duration of isotretinoin treatment ranged from 4 to 12 months, with $85.7 \%$ of the population having used the drug for 5-7 months. The patients evaluated took daily doses of isotretinoin that ranged from 20 to $80 \mathrm{mg}$, with a mean of $41.43 \pm 10.53 \mathrm{mg}$ per day. AST, ALT and triglyceride levels are required for monitoring treatment. At the beginning of treatment, mean triglyceride level was $87.01 \pm 48.25$ $\mathrm{mg} / \mathrm{dL}$, while after three months or more of treatment, this value was $105.32 \pm 48.76 \mathrm{mg} / \mathrm{dL}$. In the case of AST, the mean baseline value in these patients was $20.44 \pm 6.25 \mathrm{U} / \mathrm{L}$, while after three months or more of treatment this value was $24.38 \pm 11.9 \mathrm{U} / \mathrm{L}$. Mean ALT level increased from $18.24 \pm 8.31 \mathrm{U} / \mathrm{L}$ at baseline to $23.34 \pm 20.02 \mathrm{U} / \mathrm{L}$ after three months or more of treatment. Taking into consideration the NCI criteria and comparing baseline values with those measured after three months or more of treatment, the incidence of laboratory alterations was greater in the case of AST (from $0 \%$ to $8.6 \% ; \mathrm{p}=1.0$ ) and triglycerides (from $8.6 \%$ to $17.1 \%$; $\mathrm{p}<0.001$ ), followed by ALT (from $1.4 \%$ to $7.1 \% ; \mathrm{p}=0.780$; Figure 1 ).

The incidence of patients whose normal biochemical baseline values changed after three or more months is described in table 1 . These results differ from those presented above, since they refer only to patients with normal values prior to treatment, excluding those patients with uncontrolled levels at baseline.

When the mean difference was calculated between baseline triglyceride, AST and ALT levels and those measured after three months or more of oral isotretinoin treatment, a statistically significant difference was found between the two time points (Table 2).

No correlations were found between the dose of isotretinoin administered, the daily dose per weight of the patient $(\mathrm{mg} / \mathrm{kg} / \mathrm{day})$ and the increase in triglyceride levels (Spearman's $\rho=-0.006 ; \mathrm{p}=0.961$; 


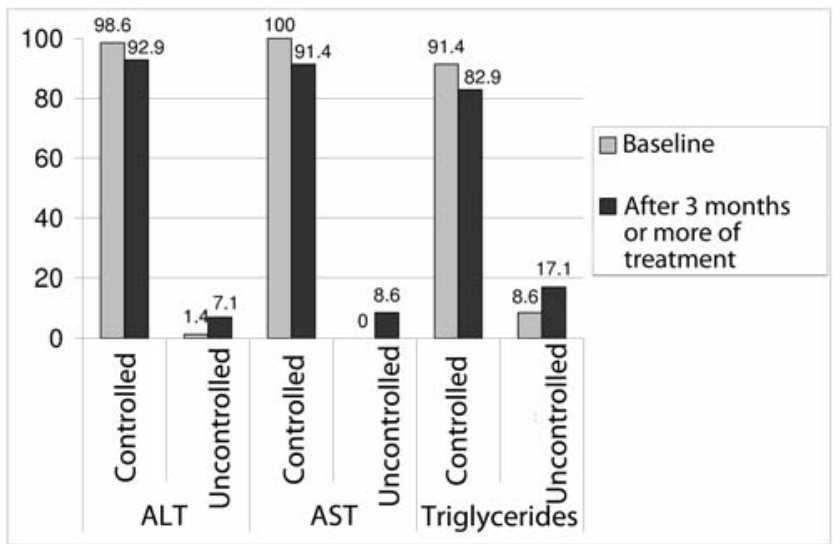

FIGURE 1: Proportion of patients with controlled and uncontrolled ALT, AST and triglyceride levels at baseline and after three months or more of oral isotretinoin treatment

Spearman's $\rho=-0.216 ; \mathrm{p}=0.074$, respectively). On the other hand, there was a correlation between increased triglyceride levels and the patient's weight (Spearman's $\rho=0.289 ; \mathrm{p}=0.016$ ). In an attempt to clarify the trend towards significance for the daily dose per weight of the patient and to establish whether this trend was related to the patient's weight or if there was some other variable that was affecting the levels of ALT, AST and triglycerides, three multiple linear regression models were constructed. In the first model, the dependent variable was ALT after three months or more of treatment, while in the second model the dependent variable was AST after three months or more of treatment and in the third model the dependent variable was triglycerides after three months or more of treatment. The following independent variables were added to the model: dose $(20,30$, 40 or $60 \mathrm{mg} / \mathrm{kg} / \mathrm{day}$ ), the patient's weight in $\mathrm{kg}$, duration of treatment, the patients' age, baseline glucose

TABLE 1: Incidence of patients with normal levels at baseline and altered values after 3 or more months of oral isotretinoin treatment

\begin{tabular}{lll} 
Laboratory tests & $\mathbf{n}$ & $\%$ \\
\hline ALT & $\mathrm{n}=69$ & \\
Normal $(<40 \mathrm{U} / \mathrm{L})$ & 64 & 92.7 \\
Uncontrolled $(>40 \mathrm{U} / \mathrm{L})$ & 5 & 7.3 \\
AST $(\mathrm{U} / \mathrm{L})$ & $\mathrm{n}=70$ & \\
Normal $(<40 \mathrm{U} / \mathrm{L})$ & 64 & 91.4 \\
Uncontrolled $(>40 \mathrm{U} / \mathrm{L})$ & 6 & 8.6 \\
& & \\
TRIGLYCERIDES & $\mathrm{n}=64$ & 89 \\
Normal $(<150 \mathrm{mg} / \mathrm{dL})$ & 57 & 11 \\
Uncontrolled $(>150 \mathrm{mg} / \mathrm{dL})$ & 7 & \\
\hline
\end{tabular}

levels, baseline prothrombin time and baseline total cholesterol level. The backwards entry method was used in this analysis, which showed that no independent variable was capable of explaining the model.

\section{DISCUSSION}

The results of this study showed that the mean age of the women was greater than the mean age of the men, possibly because acne usually affects men at puberty due to hormone changes, while women are more often affected in adulthood. This may occur due to the effect of neuromediators and the state of hyperandrogenism on the persistence of acne, as well as on the delayed onset of the disease. ${ }^{17}$

Oral treatment with isotretinoin for three months or longer induces alterations in triglyceride, AST and ALT levels. Although various studies have confirmed these results, the magnitude of the alterations has varied greatly between studies. ${ }^{12,14,18-22}$ These differences may be explained by the considerably diverse sample sizes, since smaller sample sizes may reduce the precision of calculations. Furthermore, there was no homogeneity between studies with respect to the criteria used to define normal and abnormal laboratory results, which limits any comparisons. Moreover, these considerations may explain the fact that other studies have failed to find any significant alterations in triglyceride levels or liver aminotransferases. ${ }^{15}$

The increase in triglyceride levels in patients being treated with oral isotretinoin may be related to a reduction in the removal rate of these lipids from plasma. $^{23}$ It also appears to be influenced by the increase in gene expression for Apo $\mathrm{E}^{24}$

In agreement with reports from other studies, no correlation was found between the oral dose of isotretinoin and the increase in triglycerides. ${ }^{12,25}$ Furthermore, there appears to be no correlation between the cumulative dose of isotretinoin and the magnitude of the increase in triglycerides. In addition, no significant increases occur with chronic treatment over long periods. ${ }^{26}$ As in previous studies, increased triglyceride levels did not reach more than twice the upper limit of the normal range, a situation that would justify interrupting treatment. ${ }^{19}$ Moreover, studies that monitored patients after the end of treatment reported that the increase in triglyceride levels appears to be reversible in the majority of patients, suggesting that adjustments to the patient's diet and the introduction of regular physical activity would be sufficient to control triglyceride levels in patients treated with isotretinoin. ${ }^{12,22}$ On the other hand, there was a correlation between the patient's weight and triglyceride levels after three months or more of treatment. This finding raises a concern, since there is a possibility that this increase in triglyceride levels during iso- 
TABLE 2: Mean difference in triglyceride, AST and ALT levels in each patient at baseline and after three months or more of oral isotretinoin treatment.

\begin{tabular}{lllll}
\hline & Mean difference & $\mathbf{n}$ & Paired-Samples Test & p-value \\
\hline $\begin{array}{l}\text { Triglycerides at baseline - } \\
\begin{array}{l}\text { Triglycerides after three months } \\
\text { or more of treatment }\end{array}\end{array}$ & 18.31 & 70 & -3.213 & 0.002 \\
& & & & \\
AST at baseline - AST after three & 3.93 & 70 & -2.533 & 0.014 \\
$\begin{array}{l}\text { months or more of treatment. } \\
\begin{array}{l}\text { ALT at baseline - ALT after three } \\
\text { months or more of treatment. }\end{array}\end{array}$ & 5.10 & 70 & -2.025 & 0.047 \\
\hline
\end{tabular}

tretinoin treatment may increase the risk of developing metabolic syndrome. ${ }^{24}$

Other studies have also shown an increase in the LDL-cholesterol fraction and a reduction in the HDL fraction, together with an increase in triglycerides in patients in use of isotretinoin for eight weeks or more. ${ }^{22,27}$ These alterations serve as a warning of a possible increased cardiovascular risk in these patients. However, the alterations in the lipid profile of these patients induced by isotretinoin appear to be transitory, since they return to baseline levels approximately eight weeks after the end of treatment. ${ }^{22}$ In addition, when using the total cholesterol/HDL cholesterol ratio to estimate cardiovascular risk, although a statistically significant increase in this ratio occurs in patients using retinoids, this risk continues to be classified as moderate. $^{27}$ As a whole, these results suggest that more frequent monitoring is justified with respect to the lipid profile of patients undergoing treatment with isotretinoin who already have some cardiovascular risk factor. It should be emphasized that total cholesterol and fractions were included as follow-up tests for the use of oral isotretinoin in the Ministry of Health's Clinical and Therapeutic Guidelines Protocol published on March 31, 2010. These tests were not required in the earlier protocol published in 2001. ${ }^{28}$

Although the present study found statistically significant increases in liver aminotransferases, they were clinically irrelevant in the majority of patients. Only one patient had an increase in ALT that was classified as grade 2 , i.e. $\geq 2.0$ times the upper limit of normal. In situations such as this, Altman et al. suggest interrupting treatment due to the risk of developing liver disease. ${ }^{19}$

The increased levels of triglyceride, AST and ALT found in the present study reinforce the importance of having the patient monitored by a multidisci- plinary team. The patient should be counseled on the importance of a balanced diet with low fat intake and restricted alcohol consumption in order to prevent or minimize possible biochemical alterations that contribute towards increasing the risk of cardiovascular, metabolic or liver disease. In this respect, various studies have shown that the introduction of certain food supplements into the patient's diet may prevent or minimize the increases in triglyceride levels caused by oral isotretinoin treatment. ${ }^{29,30}$

Multiple linear regression analysis showed that none of the independent variables was able to explain the model, although there were correlations between some variables in the univariate analysis. This trend in correlation between the variables and the biochemical results highlights the need to conduct studies with larger sample sizes.

Finally, the present study was limited to analyzing the biochemical abnormalities without taking into consideration the follow-up data on the clinical repercussions that these abnormalities may have caused in the patients. The study also failed to register the occurrence of adverse events that could have predicted the alterations in the lipid profile and liver function, since this was a retrospective study based on secondary data. In this respect, the importance of conducting prospective studies to evaluate these aspects should be emphasized in view of the fact that findings may lead to adjustments to the current guidelines.

\section{CONCLUSION}

These results show that in the population evaluated in this study the use of oral isotretinoin for the treatment of acne led to increases in serum triglyceride, ALT and AST levels. Although these alterations did not require treatment to be interrupted, they may 
increase the patient's risk of developing cardiovascular and liver disease, confirming data already published in the literature. For this reason, rigorous monitoring with lipid profile measurements and liver function tests is indispensable in order to minimize the inherent risks of treatment with this drug.

\section{REFERENCES}

1. 1. Cordain L, Lindeberg S, Hurtado M, Hill K, Eaton SB, Brand-Miller J. Acne vulgaris: a disease of Western civilization. Arch Dermatol. 2002;138:1584-90.

2. 2. Sociedade Brasileira de Dermatologia [Internet]. Censo Dermatológico da SBD. 2006 [accessed on 29 March, 2010]. Available at: http://www.sbd.org.br/down/censo dermatologic02006.pdf

3. 3. Bershad SV. The Modern Age of Acne Therapy: A Review of Current Treatment Options. Mt Sinai J Med. 2001;68:279-86.

4. 4. Sampaio S, Rivitti E. Dermatologia. São Paulo: Artes Médicas; 2001.

5. 5. Sampaio SAP, Bagatin E. Experiência de 65 anos no tratamento da acne e de 26 anos com isotretinoína oral. An Bras Dermatol. 2009:83:361-7.

6. 6. Ministério da Saúde. Portaria SAS/MS n $n^{0}$ 389, de 19 de setembro de 2001. Protocolo clínico e diretrizes terapêuticas. Diário oficial da União19 de set de 2001.

7. 7. Cooper AJ. Treatment of acne with isotretinoin: recommendations based on Australian experience. Astralas J Dermatol. 2003:44:97-105.

8. 8. Merritt B, Burkhart CN, Morrell DS. Use of isotretinoin for acne vulgares. Pediatr Ann. 2009;38:331-20.

9. 9. Nelson AM, Gilliland KL, Cong Z, Thiboutot DM. 13-cis Retinoic acid induces apoptosis and cell cycle arrest in human SEB-1 sebocytes. J Invest Dermatol 2006;126:2178-89.

10. 10. Bozkurt B, Irkec MT, Atakan N. Lacrimal function and ocular complications in patients treated with systemic isotretinoin. Eur J Ophthalmol. 2002;12:173-6.

11. 11. Kaymak $Y$, llter $N$. The results and side effects of systemic isotretinoin treatment in 100 patients with acne vulgaris. Dermatol Nurs. 2006:18:576-80.

12. 12. Zane LT, Leyden WA, Marqueling AL, Manos MM. A population-based analysis of laboratory abnormalities during isotretinoin therapy for acne vulgaris. Arch Dermatol. 2006;142:1016-22

13. 13. Vu-Dac N, Gervois P, Torra IP, Fruchart JC, Kosykh V, Kooistra T, et al. Retinoids increase human apo $\mathrm{C}$-III expression at the transcriptional level via the retinoid $\mathrm{X}$ receptor: contribution to the hypertriglyceridemic action of retinoids. J Clin Invest. 1998; 102:625-32.

14. 14. Júnior EDS, Sette IMF, Belém LF, Janebro DI, Pereira GJS, Barbosa JAA, et al. Isotretinoína no tratamento da acne: riscos $\mathrm{x}$ benefícios Rev Bras Farm. 2009;90:186-9

15. 15. Brito Mde F, Sant'Anna IP, Galindo JC, Rosendo LH, Santos JB. Avaliação dos efeitos adversos clínicos e alterações laboratoriais em pacientes com acne vulgar tratados com isotretinoína oral. An Bras Dermatol. 2010;85:331-7.

16. 16. National Institutes of Health. National Cancer Institute. Common Terminology Criteria for Adverse Events v3.0 (CTCAE). Bethesda, Md: National Cancer Institute; 2003.

17. 17. Teixeira MAG, França ER. Mulheres adultas com acne: aspectos comportamentais, perfis hormonal e ultra-sonográfico ovariano. Rev Bras Saúde Matern Infant. 2007;7:39-44.

18. 18. Michaëlsson G, Vahlquist A, Mobacken H, Hersle K, Landegren J, Rönnerfält L, et al. Changes in laboratory variables induced by isotretinoin treatment of acne. Acta Derm Venereol. 1986;66:144-8.

19. 19. Altman RS, Altman LJ, Altman JS. A Proposed Set of New Guidelines for Routine Blood Tests during Isotretinoin Therapy for Acne vulgaris. Dermatology. 2002;204:232-5.
Furthermore, it is important to emphasize the role of the pharmacist in the pharmacotherapeutic follow-up interview to ensure that the drug is dispensed appropriately and that the patients are being adequately monitored.
20. 20. Tallab $T$, Joharii H, Jazei M, Bahamdan K, Ibrahim K, Karkashan E. Isotretinoin therapy: any need for laboratory assessment? West Afr J Med. 2004;23:273-5.

21. 21. Bener A, Lestringant GG, Ehlayel MS, Saarinen K, Takiddin AH. Treatment outcome of acne vulgaris with oral isotretinoin. J Coll Physicians Surg Pak. 2009;19:49-51.

22. 22. Bershad S, Rubinstein A, Paterniti JR, Le NA, Poliak SC, Heller B, et al. Changes in plasma lipids and lipoproteins during Isotretinoin therapy for acne. N Engl J Med. 1985;313:981-5.

23. 23. De Marchi MA, Maranhao RC, Brandizzi LI, Souza DR. Effects of isotretinoin on the metabolism of triglyceride-rich lipoproteins and on the lipid profile in patients with acne. Arch Dermatol Res. 2006:297:403-8.

24. 24. Rodondi N, Darioli R, Ramelet AA, Hohl D, Lenain V, Perdrix J, et al. High risk for hyperlipidemia and the metabolic syndrome after an episode of hypertriglyceridemia during 13-cis-retinoic acid therapy for acne: A pharmacogenetic study. Ann Intern Med. 2002;136:582-9.

25. 25. McLane J. Analysis of common side effects of isotretinoin. J Am Acad Dermatol. 2001:45:S188-94.

26. 26. Lestringant GG, Frossard PM, Agarwal M, Galadari IH. Variations in lipid and lipoprotein levels during isotretinoin treatment for acne vulgaris with special emphasis on HDL-cholesterol. Int J Dermatol. 1997;36:859-62.

27. 27. Ministério da Saúde. Portaria SAS/MS no 143, de 31 de março de 2010 Protocolo clínico e diretrizes terapêuticas: acne grave. Diário oficial da União $01 \mathrm{de}$ abril de 2010

28. 28. Radcliffe JD, Czaika-Narins DM. A Comparison of the effectiveness of soy protein isolate and fish oil for reducing the severity of retinoid induced hypertriglyceridemia. Nutr Biochem. 2004;15:163-8.

29. 29. Brelsford M, Beute TC. Preventing and managing the side effects of isotretinoin Semin Cutan Med Surg. 2008:27:197-206.

30. 30. Baxter KF, Ling TC, Barth JH, Cunliffe WJ. Retrospective survey of serum lipids in patients receiving more than three courses of isotretinoin. $J$ Dermatolog Treat. 2003:14:216-8

\author{
MAILING ADDRESS: \\ Ana Carolina Melchiors \\ Rodovia BR 101 norte, Km. 60 - Bairro Litorâneo. \\ 29932-540 São Mateus, ES, Brazil \\ E-mail:anamelchiors@ceunes.ufes.br
}

How to cite this article: Vieira AS, Beijamini V, Melchiors AC. The effect of isotretinoin on triglycerides and liver aminotransferases. An Bras Dermatol. 2012;87(3):382-7. 